\title{
How cold is too cold? Establishing the minimum water temperature limits for marathon swim racing
}

\author{
Jane Saycell, Mitch Lomax, Heather Massey, Mike Tipton
}

Department of Sport and Exercise Science, University of Portsmouth, Portsmouth, UK

\section{Correspondence to} Professor Mike Tipton, Department of Sport and Exercise Science, University of Portsmouth, Portsmouth P01 2UP, UK;

michael.tipton@port.ac.uk

Accepted 28 January 2019 Published Online First 1 March 2019

\section{Linked}

- http://dx.doi.org/10.1136/ bjsports-2019-100646

Check for updates

(C) Author(s) (or their employer(s)) 2019. No commercial re-use. See rights and permissions. Published by BMJ.

\section{To cite: Saycell J,}

Lomax M, Massey $\mathrm{H}_{\text {, }}$

et al. Br I Sports Med

2019:53:1078-1084.

\author{
ABSTRACT \\ Objectives To provide a rationale for minimum water \\ temperature rules for elite and subelite marathon swim \\ racing and highlight factors that make individuals \\ vulnerable to excessive cooling during open water \\ swimming.
}

Methods 12 lean competitive swimmers swam for up to 2 hours, three times in different water temperatures between $14^{\circ} \mathrm{C}$ and $20^{\circ} \mathrm{C}$, wearing standard swimming costumes and hats. Rectal temperature $\left(\mathrm{T}_{\mathrm{re}}\right)$, oxygen consumption, perception of cold and performance were measured.

Results In $16^{\circ} \mathrm{C}$, half the swimmers did not complete a 2-hour swim; four became (or were predicted to become) hypothermic within 2 hours. In $18^{\circ} \mathrm{C}$, three-quarters completed the swim; three became (or were predicted to become) hypothermic. In $20^{\circ} \mathrm{C}$, one swimmer was predicted to become hypothermic in under 2 hours. The mean linear rate of fall of $\mathrm{T}_{\mathrm{re}}$ was greater in $16^{\circ} \mathrm{C}$ $\left(-1.57^{\circ} \mathrm{C} /\right.$ hour $)$ than $18^{\circ} \mathrm{C}\left(-1.07^{\circ} \mathrm{C} /\right.$ hour $)(p=0.03)$. There was no change in swimming performance during the swims or between conditions. Most of the cooling rate could be explained by metabolic heat production and morphology for both $16^{\circ} \mathrm{C}\left(R^{2}=0.94, p<0.01\right)$ and $18^{\circ} \mathrm{C}\left(R^{2}=0.82, p<0.01\right)$ conditions. No relationship was observed between $T_{\text {re }}$ and perception of thermal sensation $(r=0.25, p=0.13)$, and there was a weak correlation between $T_{r e}$ and thermal comfort $(r=0.32$, $\mathrm{p}=0.04$ ).

Conclusion We recommend that $16^{\circ} \mathrm{C}$ and $18^{\circ} \mathrm{C}$ water are too cold for elite marathon swim racing. FédérationInternationale de Natation rules were changed in 2017 to make wetsuits compulsory below $18^{\circ} \mathrm{C}$ and optional below $20^{\circ} \mathrm{C}$.

\section{INTRODUCTION}

Open water swimming in cold water is an increasingly popular leisure and sporting pastime. However, as evidence by a spate of deaths of otherwise healthy young people in the UK over the summer of 2018, such swimming is not without its risks. These range from cardiorespiratory problems on initial immersion to hypothermia during longer exposures.

Hypothermia is defined as a deep body temperature of below $35^{\circ} \mathrm{C}^{1}$ : swimmers should keep their body temperature above this level for safety. Also, swimming performance usually deteriorates due to peripheral neuromuscular cooling before rectal temperature reaches $35^{\circ} \mathrm{C}$, evidenced by shorter strokes, higher stroke rate, increased swim angle and reduced efficiency, all of which are precursors to swim failure. ${ }^{2}$ It is unclear, but thought doubtful, whether swimmers are able to judge their own deep body temperature in order to withdraw from events before becoming hypothermic. ${ }^{3}$

Humans vary widely in their ability to maintain body temperature at or close to $37^{\circ} \mathrm{C}$ in cold water; some can maintain body temperature while swimming in water at $10^{\circ} \mathrm{C},{ }^{4}$ but others cannot at $18^{\circ} \mathrm{C}^{23}$ The main factor in maintaining deep body temperature when swimming is the amount of body fat, with thinner swimmers showing more rapid falls in temperature due to lower levels of insulation. $^{24}$

The Fédération Internationale de Natation (FINA) governs all swim racing. Elite marathon races may be held over distances from $5 \mathrm{~km}$ to $32 \mathrm{~km}$. The Olympic race distance is $10 \mathrm{~km}$, and this exposes elite athletes to cold water for approximately 2 hours. Marathon swim racing has minimum water temperatures rules; when we undertook the present study, wetsuits were prohibited for elite racing, and the minimum water temperature for racing was $16^{\circ} \mathrm{C} .^{5}$ There were no scientific data underpinning this rule. We aimed to: (1) study factors that make swimmers vulnerable to cooling and (2) recommend a safe minimum water temperature limit.

\section{METHODS}

\section{Participants}

Twelve participants (six men and six women) were recruited to the study. All gave written, informed consent, were physically fit and healthy, aged 17 years or over, endurance-trained swimmers and competing as youth elites or open water masters. Detailed characteristics are included in table 1.

Athletes wore their own swimsuits and goggles throughout the study and were provided with a standard silicon swimming hat. On each test visit, participants were asked to arrive well rested and refreshed as though for a race.

\section{Procedures}

Familiarisation with the swimming flume and other equipment was carried out on a separate day prior to testing: participants swam for as long as they wished to ascertain the flume speed that they felt most approximated their $10 \mathrm{~km}$ race pace; this was then used as the initial speed for test visits.

On each visit, participants were instrumented with a rectal thermistor (Grant Instruments [Cambridge] Ltd, UK), self-inserted $15 \mathrm{~cm}$ beyond the anal sphincter. Heart rate was monitored using a chest strap heart rate monitor and watch (Polar, UK), recorded at $5 \mathrm{~min}$ intervals. Participants then entered the water and waited for $3 \mathrm{~min}$ to allow breathing and heart rate to recover from the cold shock response before swimming for 2 hours in a 
Table 1 Characteristics of study participants ordered by least-tomost skinfold thickness

\begin{tabular}{clllll}
\hline ID & Sex & $\begin{array}{l}\text { Age } \\
(\text { years })\end{array}$ & $\begin{array}{l}\text { Height } \\
(\mathbf{m})\end{array}$ & $\begin{array}{l}\text { Mass } \\
(\mathbf{k g})\end{array}$ & $\begin{array}{l}\text { Sum of seven } \\
\text { skinfolds }(\mathbf{m m})\end{array}$ \\
\hline 1 & Male & 17 & 1.80 & 65.58 & 43.15 \\
\hline 2 & Male & 41 & 1.74 & 75.73 & 50.60 \\
\hline 3 & Female & 41 & 1.74 & 56.40 & 51.05 \\
\hline 4 & Female & 33 & 1.65 & 55.81 & 60.75 \\
5 & Male & 32 & 1.87 & 84.00 & 77.90 \\
\hline 6 & Male & 28 & 1.76 & 76.00 & 83.55 \\
\hline 7 & Male & 34 & 1.76 & 81.90 & 92.90 \\
\hline 8 & Female & 45 & 1.72 & 64.96 & 92.25 \\
\hline 9 & Female & 43 & 1.81 & 65.59 & 95.60 \\
\hline 10 & Male & 45 & 1.77 & 71.48 & 101.70 \\
11 & Female & 26 & 1.67 & 63.09 & 106.75 \\
\hline 12 & Female & 31 & 1.84 & 73.42 & 139.65 \\
\hline Mean (SD) & & $35(8)$ & $1.76(0.06)$ & $69.50(8.74)$ & $83.24(26.94)$ \\
\hline
\end{tabular}

temperature-controlled flume (SwimEx 600-T Therapy Pool, length $4.2 \mathrm{~m}$, width $2.3 \mathrm{~m}$ and depth $1.5 \mathrm{~m}$ ). The swim was self-paced, and athletes were asked to maintain $10 \mathrm{~km}$ race pace, but they could change the speed at any time by signalling the researchers. The speed of the flume was measured by a current meter (Braystroke Model 001 Open Channel Flow meter, Valeport, UK), positioned $10 \mathrm{~cm}$ from the surface of the water immediately in front of the swimmer's outstretched hand when above their head. Distance swum was calculated from duration at each speed.

All participants attempted swims at $16^{\circ} \mathrm{C}$ (the minimum race temperature) and $18^{\circ} \mathrm{C}$. Participants completed these in a random order at the same time of day (with a minimum rest of 24 hours between swims). Those who successfully completed a $16^{\circ} \mathrm{C}$ swim then attempted a swim at $14^{\circ} \mathrm{C}$, while the remaining participants swam at $20^{\circ} \mathrm{C}$. Ambient air temperature was maintained at $18^{\circ} \mathrm{C}$.

Every $20 \mathrm{~min}$, the number of complete stroke cycles in $1 \mathrm{~min}$ was counted to assess changes in swim efficiency.

Before the start of the swim, and every 30 min during the swim, expired air measurements (ventilation $\left[\hat{V}_{\mathrm{E}}\right]$ and oxygen consumption $\left[\hat{V O}_{2}\right]$ ) were taken for 5 min using the MetaSwim metabolic cart (Cortex, Germany). After each set of expired air measurements, participants rested upright at the side of the pool in the water for $1 \mathrm{~min}$ and were allowed to drink water at ambient temperature ad libitum. At this time they were asked to note their perceptions of cold on thermal comfort and thermal sensation scales. ${ }^{6}$ The swim was stopped before the end of 2 hours if the swimmer requested to finish, or if the swimmer's $\mathrm{T}_{\mathrm{re}}$ reached $35^{\circ} \mathrm{C}$ (laboratory safety withdrawal criterion). In this situation, the swimmer was warmed in a bath $\left(40^{\circ} \mathrm{C}\right)$. If $\mathrm{T}_{\mathrm{re}}$ did not fall to $35^{\circ} \mathrm{C}$ during the swim, the swimmer exited the water after 2 hours and dried and dressed themselves. $\mathrm{T}_{\mathrm{re}}$ was monitored after the swim until it started to rise. Participants were permitted to eat and drink during this time to simulate a postrace situation.

\section{Data analyses}

The objective criteria used to decide that a water temperature was safe for marathon swimming were:

1. Swimmers were able to maintain $\mathrm{T}_{\mathrm{re}}$ above $35^{\circ} \mathrm{C}$ for 2 hours.

2. Swim performance was not impaired (based on swim speed and stroke efficiency).
3. Swimmers were able to judge when they were becoming too cold.

\section{Calculations \\ Rectal temperatures}

$\mathrm{T}_{\mathrm{re}}$ was normalised and change in temperature was plotted against time from entry into the water. Where $T_{r e}$ fell during the swim, the time at which the fall became linear was noted, and the linear rate of change $(\mathrm{RoC})$ of $\mathrm{T}_{\mathrm{re}}\left({ }^{\circ} \mathrm{C} /\right.$ hour$)$ was calculated from the gradient of the plotted linear line. Where a swimmer was not withdrawn due to hypothermia, the RoC was used to predict how long the swimmer would be able to continue before becoming hypothermic using the formula: Time to hypother$\mathrm{mia}=\mathrm{a}+(35-\mathrm{b}) / \mathrm{c}$

Where $\mathrm{a}=$ time for $\mathrm{T}_{\mathrm{re}}$ to start falling linearly; $\mathrm{b}=\mathrm{T}_{\mathrm{re}}$ at start of the linear fall; $\mathrm{c}=\mathrm{RoC}$.

The prediction was compared with actual time to hypothermia $\left(\mathrm{T}_{\mathrm{re}}=35^{\circ} \mathrm{C}\right)$ for participants who were withdrawn. As this only happened on three occasions, numbers did not allow for statistical analysis, but in each case the predicted time was within 2 min of the actual time (2.21\%-5.61\% of actual time).

\section{Physical characteristics calculations}

Body surface area (BSA) was estimated according to the formula ${ }^{7}$ : BSA $\left(\mathrm{m}^{2}\right)=0.007184 \times$ mass $^{0.425}(\mathrm{~kg}) \times$ height $^{0.725}(\mathrm{~m})$.

Sum of skinfolds (SSF) and mean heat production (MHP) divided by BSA were combined into a single measure (SSF $\times$ $\mathrm{MHP} / \mathrm{BSA}$ ), as this gives a single figure that indicates MHP, insulation from subcutaneous fat and heat loss through convection/ conduction (major routes for heat loss in water). Leaner individuals tend to have smaller values for SSF $\times \mathrm{MHP} / \mathrm{BSA}$, while larger individuals with more body fat have higher values.

\section{Performance}

Mean swim speed (m/s) was calculated from time (s) spent swimming at each speed. Distance per stroke cycle was calculated as a measure of efficiency by swim speed (as metres per minute)/ number of strokes per minute. ${ }^{2}$

\section{Heat production calculations}

$\dot{V}_{\mathrm{E}}$ and $\hat{V} \mathrm{O}_{2}$ were averaged from breath by breath data over the final $3 \mathrm{~min}$ of each collection and used to calculate MHP, according to the following formula ${ }^{8}$ : Heat production (watts) $=-$ mechanical efficiency $\times$ energy input

Where energy input was calculated from expired air measurements based on the Weir method, ${ }^{9}$ and mechanical efficiency was calculated using the efficiency values of Toussaint et al. ${ }^{10}$

\section{Statistical analyses}

Data were tested for normality using Shapiro-Wilk test, and $\mathrm{p}$ was set at equal to or less than 0.05 and calculated using IBM SPSS V.22.

Paired t-tests were used to compare linear RoC of $T_{r e}$ and predicted (or actual) time to hypothermia, mean swim speed and distance per stroke cycle at the end of the swim for participants between $16^{\circ} \mathrm{C}$ and $18^{\circ} \mathrm{C}$ conditions, and between $18^{\circ} \mathrm{C}$ and $20^{\circ} \mathrm{C}$ for those who participated in this condition. Numbers completing the $14^{\circ} \mathrm{C}$ condition were too low for statistical comparison.

Effect sizes were calculated using Cohen's $d$ to assess the impact of the water temperature on each variable. Cohen's $d$ scores were valued as follows ${ }^{11}: 0.2=$ small effect; $0.6=$ moderate 


\section{Original article}

Table 2 Participants who attempted a 2-hour swim in each condition and the outcome, ordered by least-to-most skinfold thickness

\begin{tabular}{|c|c|c|c|c|c|c|c|c|c|c|c|c|c|}
\hline & 1 & 2 & 3 & 4 & 5 & 6 & 7 & 8 & 9 & 10 & 11 & 12 & $\begin{array}{l}\text { Total } \\
\text { completed }\end{array}$ \\
\hline $14^{\circ} \mathrm{C}$ & & & & & & C & $\begin{array}{l}\text { S (66, } \\
\text { unwell) }\end{array}$ & W (78) & & & & C & $2 / 4$ \\
\hline $16^{\circ} \mathrm{C}$ & S (34) & W (60) & S (64) & $S(42)$ & $S(106)$ & C & C & C & $S(111)$ & C & C & C & $6 / 12$ \\
\hline $18^{\circ} \mathrm{C}$ & $S(64)$ & W (90) & C & $S(49)$ & C & C & C & C & C & C & C & C & $9 / 12$ \\
\hline $20^{\circ} \mathrm{C}$ & S (95) & C & $\begin{array}{l}S(65, \\
\text { injury) }\end{array}$ & $\begin{array}{l}\text { S (47, } \\
\text { cramp) }\end{array}$ & C & & & & & & C & & $3 / 6$ \\
\hline
\end{tabular}

C, completed condition; S, stopped swim early (time and reason if not due to cold); $\mathrm{W}$, withdrawn due to $\mathrm{T}_{\mathrm{re}}$ falling to $35^{\circ} \mathrm{C}$ (time in minutes).

effect; 1.2 =large effect; 2 =very large effect; 4 =extremely large effect.

Forward linear regression was used to assess the correlation between TC and $\mathrm{T}_{\mathrm{re}}$ and TS and $\mathrm{T}_{\mathrm{re}}$, and the correlation between $\mathrm{SSF} \times \mathrm{MHP} / \mathrm{BSA}$ and linear $\mathrm{RoC}$ of $\mathrm{T}_{\text {re }}$ for $16^{\circ} \mathrm{C}$ and $18^{\circ} \mathrm{C}$ conditions.

\section{RESULTS}

\section{Completing conditions}

Table 2 shows the outcome of each condition attempted by participants.

\section{Deep body temperature}

The number of participants whose $T_{\text {re }}$ fell and the number becoming (or predicted to become) hypothermic during each condition are shown in table 3 . Six out of the 12 swimmers were unable to complete a 2 -hour swim at $16^{\circ} \mathrm{C}$, and 4 out of 12 either became hypothermic or were predicted to become so in less than 2 hours. In $18^{\circ} \mathrm{C}$, three swimmers were predicted to become hypothermic within the 2 hours. One swimmer was predicted to become hypothermic in the $20^{\circ} \mathrm{C}$ condition.

For those whose $\mathrm{T}_{\mathrm{re}}$ fell during the condition, the linear RoC of $T_{r e}$ and actual or predicted time to hypothermia for each condition are shown in table 3 . There was a significant difference in linear RoC between the $16^{\circ} \mathrm{C}\left(-1.57^{\circ} \mathrm{C} /\right.$ hour $)$ and $18^{\circ} \mathrm{C}$ $\left(-1.07^{\circ} \mathrm{C} /\right.$ hour $)$ conditions $(p=0.03)$.

\section{Swim performance}

Mean swim speed and distance per stroke cycle for each condition are shown in table 3. There was no difference in swim speed or distance per stroke cycle between conditions, and no participant was withdrawn due to swim failure, although two swimmers stopped due to cramp, and in eight cases, swimmers stopped before 2 hours stating that they were too cold to swim (time and reason shown in table 2).

\section{Thermal perception}

Figure 1 shows thermal sensation and thermal comfort scores plotted against $\mathrm{T}_{\mathrm{re}}$ for all participants in all conditions. There was no correlation between $T_{r e}$ and thermal sensation $(r=0.25$, $\mathrm{p}=0.13$ ) and a weak significant correlation between $T_{r e}$ and thermal comfort $(\mathrm{r}=0.32, \mathrm{p}=0.04)$.

\section{Factors in cooling}

Figure 2 shows the calculated variable SSF $\times$ MHP/BSA plotted against the linear $\mathrm{RoC}$ of $\mathrm{T}_{\mathrm{re}}$ for $16^{\circ} \mathrm{C}$ and $18^{\circ} \mathrm{C}$ conditions. There was a very strong correlation for both conditions $\left(16^{\circ} \mathrm{C}: \mathrm{r}=0.98\right.$, $\left.\mathrm{p}<0.01 ; 18^{\circ} \mathrm{C}: \mathrm{r}=0.92, \mathrm{p}<0.01\right)$, indicating a very high degree of the variance could be explained by SSF $\times \mathrm{MHP} / \mathrm{BSA}\left(16^{\circ} \mathrm{C}\right.$ : $\left.\mathrm{R}^{2}=0.94 ; 18^{\circ} \mathrm{C}: \mathrm{R}^{2}=0.82\right)$. Most of the variance was explained by SSF $\left(16^{\circ} \mathrm{C}: \mathrm{R}^{2}=0.57, \mathrm{p}<0.01 ; 18^{\circ} \mathrm{C}: \mathrm{R}^{2}=0.61, \mathrm{p}<0.01\right)$, with the model improved by including $\mathrm{MHP} / \mathrm{BSA}$ (change in $\mathrm{R}^{2} 16^{\circ} \mathrm{C}=0.24, \mathrm{p}=0.01$; change in $\left.\mathrm{R}^{2} 18^{\circ} \mathrm{C}=0.25, \mathrm{p}<0.01\right)$.

Table 3 Comparison of change in $\mathrm{T}_{\mathrm{re}}$ and performance between conditions

\begin{tabular}{|c|c|c|c|c|c|c|c|c|}
\hline & $14^{\circ} \mathrm{C}$ & $16^{\circ} \mathrm{C}$ & $18^{\circ} \mathrm{C}$ & $20^{\circ} \mathrm{C}$ & $P$ valuet & Effect size $†$ & $P$ value $\ddagger$ & Effect size \\
\hline $\mathrm{n}$ & 4 & 12 & 12 & 6 & & Cohen's d & & Cohen's d \\
\hline No. of whose $T_{r e}$ fell & 3 & 11 & 10 & 4 & - & - & - & - \\
\hline $\begin{array}{l}\text { No. reaching } 35^{\circ} \mathrm{C} \text { in under } 120 \mathrm{~min} \text { (actual and } \\
\text { predicted times) }\end{array}$ & 1 & 4 & 3 & 1 & - & - & - & - \\
\hline $\begin{array}{l}\text { Shortest time to fall to } 35^{\circ} \mathrm{C} \text { (min) (actual or } \\
\text { predicted) }\end{array}$ & 80.76 & 50.71 & 72.00 & 98.27 & - & - & - & - \\
\hline Mean (SD) linear rate of change of $\mathrm{T}_{\mathrm{re}}\left({ }^{\circ} \mathrm{C} / \mathrm{hr}\right)$ & $-1.34(0.31)$ & $-1.57(1.08)$ & $-1.07(0.75)$ & $-1.38(0.58)$ & $0.03^{*}$ & $0.57 \S$ & 0.43 & 0.569 \\
\hline $\begin{array}{l}\text { Mean (SD) time for } \mathrm{T}_{\text {re }} \text { to fall to } 35^{\circ} \mathrm{C}(\mathrm{min}) \\
\text { (actual and predicted) }\end{array}$ & $128.46(38.27)$ & $222.34(197.43)$ & $408.43(580.53)$ & $153.09(74.27)$ & 0.34 & $0.4 \S$ & 0.30 & $0.9^{* *}$ \\
\hline Mean (SD) swim speed (m/s) & $1.17(0.06)$ & $1.24(0.10)$ & $1.26(0.08)$ & $1.32(0.07)$ & 0.22 & $0.25 \S$ & 0.78 & 0.249 \\
\hline $\begin{array}{l}\text { Mean distance (SD) per stroke cycle }(\mathrm{m}) \text { at } 20 \\
\min \end{array}$ & $2.52(0.20)$ & $2.57(0.29)$ & $2.63(0.27)$ & $2.78(0.40)$ & 0.36 & 0.19 & 0.34 & $0.24 \rrbracket$ \\
\hline $\begin{array}{l}\text { Mean (SD) distance per stroke cycle }(\mathrm{m}) \text { at } \\
\text { finish }\end{array}$ & $2.39(0.16)$ & $2.51(0.35)$ & $2.47(0.23)$ & $2.58(0.30)$ & 0.58 & 0.17 & 0.47 & 0.219 \\
\hline
\end{tabular}

*Significant difference between conditions $(p \leq 0.05)$.

tBetween $16^{\circ} \mathrm{C}$ and $18^{\circ} \mathrm{C}$ conditions.

$\ddagger$ Between $18^{\circ} \mathrm{C}$ and $20^{\circ} \mathrm{C}$ conditions.

$\S S$ mall/medium effect of water temperature between $16^{\circ} \mathrm{C}$ and $18^{\circ} \mathrm{C}$ conditions.

$\eta$ Small/medium effect of water temperature between $18^{\circ} \mathrm{C}$ and $20^{\circ} \mathrm{C}$ conditions.

** Medium/large effect of water temperature between $18^{\circ} \mathrm{C}$ and $20^{\circ} \mathrm{C}$ conditions. 


\section{A}

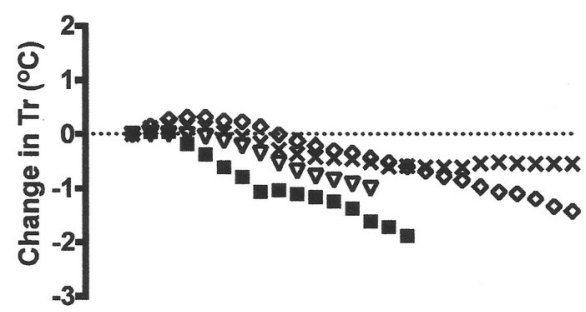

B

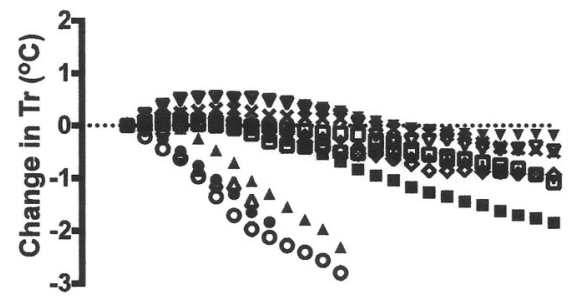

C

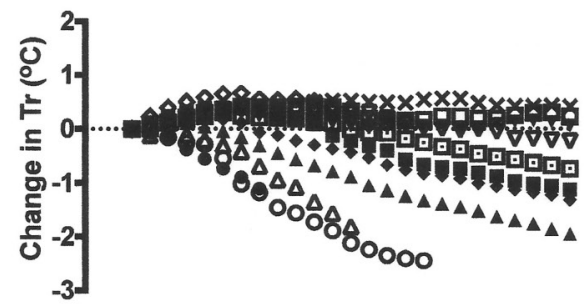

D

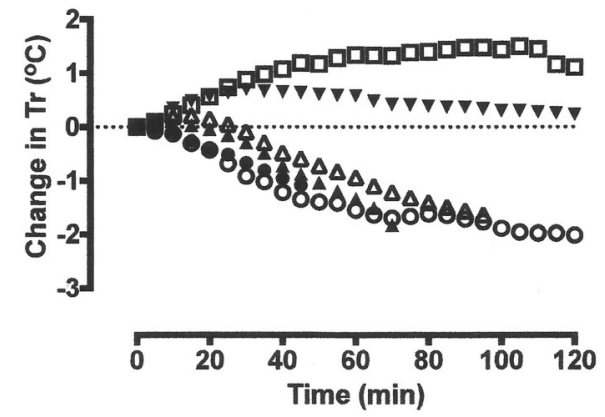

Figure $1 \mathrm{~T}_{\mathrm{re}}\left({ }^{\circ} \mathrm{C}\right)$ for all participants during the swim. $\mathrm{A}=14^{\circ} \mathrm{C}$; $B=16^{\circ} \mathrm{C} ; C=18^{\circ} \mathrm{C} ; D=20^{\circ} \mathrm{C}$. Participants numbered by skinfold thickness (least to most).

The model was very good and not improved by distinguishing between sexes $\left(16^{\circ} \mathrm{C}\right.$ male: $\mathrm{R}^{2}=0.94, \mathrm{p}<0.01$; female $=0.97$, $\mathrm{p}<0.01 .18^{\circ} \mathrm{C}$ : male $\mathrm{R}^{2}=0.77, \mathrm{p}=0.03$; female $\mathrm{R}^{2}=0.83$, $\mathrm{p}=0.02$ ). The low number of participants did not permit statistical analysis of the correlation with age or acclimatisation status.

Where swimmers completed a 2-hour swim, $\mathrm{T}_{\mathrm{re}}$ was monitored postswim until it began to rise. Where swimmers stopped early they were warmed in a bath.

\section{DISCUSSION}

We aimed to ascertain the safe minimum water temperature limits for elite marathon swim racing. It is the first study to quantify the deep body temperature and performance responses of junior elite and masters open water swimmers while swimming in cold water. As participants were lean competitive swimmers, the results are relevant to elite racing and provide evidence for rule changes. Our findings suggest that $16^{\circ} \mathrm{C}$ and $18^{\circ} \mathrm{C}$ water is too cold for elite marathon swimming. As a result of our study, FINA rules for elite marathon swim racing were changed in 2017 to make wetsuit use compulsory in water below $18^{\circ} \mathrm{C}$ and optional in water below $20^{\circ} \mathrm{C} .^{12} 13$

To decide whether a water temperature $\left(\mathrm{T}_{\mathrm{w}}\right)$ was safe for marathon swimming, we considered three criteria: (1) whether swimmers could maintain $\mathrm{T}_{\mathrm{re}}$ above $35^{\circ} \mathrm{C}$ for 2 hours, (2) whether swim performance was impaired and (3) whether swimmers were able to judge when they were becoming too cold. We also explored the factors that may influence how vulnerable an individual swimmer is likely to be to cooling.

\section{Maintaining deep body temperature}

The swimmers most vulnerable to cooling were those with the least subcutaneous fat (ie, with a sum of seven skinfolds of about $60 \mathrm{~mm}$ or less); the four leanest participants in the study cooled rapidly (rate of fall of $\mathrm{T}_{\mathrm{re}}$ ) while swimming in $16^{\circ} \mathrm{C}$, reaching $35^{\circ} \mathrm{C}$ in $50-73 \mathrm{~min}$ (Figure 3 and table 3 ). These results extend the existing literature, which indicates that maintaining deep body temperature in cold water is a substantial challenge for thin individuals due to the high heat capacity and thermal conductivity of water. ${ }^{14}$ As expected, the rate of cooling was related to $\mathrm{T}_{\mathrm{w}}$, with swimmers in $16^{\circ} \mathrm{C}$ losing heat more rapidly than in $18^{\circ} \mathrm{C}$ (a). There was no difference in RoC of $\mathrm{T}_{\mathrm{re}}$ between $18^{\circ} \mathrm{C}$ and $20^{\circ} \mathrm{C}$ water, but the number swimming in $20^{\circ} \mathrm{C}$ was small and only four of the swimmers showed any fall in $\mathrm{T}_{\mathrm{re}}$ during the $20^{\circ} \mathrm{C}$ swim, so the statistical power was poor (power $=0.46$ ). The fall in $\mathrm{T}_{\mathrm{re}}$ in both resting and exercising individuals in water has previously been shown to be proportional to $\mathrm{T}_{\mathrm{w}}{ }^{15}$ as conductive/convective cooling increases in line with the temperature gradient between the body and water. However, this relationship is particularly strong at low water temperatures when the physiological heat production and conservation mechanisms are swamped by the cooling power of the water. In warm water, the thermal and metabolic physiological response can, in some individuals, balance heat losses. This explains the wider variation seen in the thermal responses of different individuals in warmer/ cool water, and the exponential increase in estimated survival time in water above $15-18^{\circ} \mathrm{C} .{ }^{15} 16$

Heat loss in water is increased by exercise due to: increased peripheral blood flow and loss of the 'variable' insulation provided by otherwise unperfused muscle; heat from the exercising muscle transmitting directly to the skin surface; and increasing convective heat loss at the surface of the body. ${ }^{317}$ This effect is greater when using the arms, or arms and legs together, rather than leg-only exercise, ${ }^{18} 19$ and so swimmers are at particularly high risk of hypothermia in cold water. Swimmers who are lean are likely to cool more rapidly due to lower levels of the 'fixed' insulation from subcutaneous fat. ${ }^{20}$ We found that swimmers with the largest amount of subcutaneous fat were able to swim for longer (without becoming hypothermic) in $14^{\circ} \mathrm{C}$ water than could the leanest swimmers in water at $18^{\circ} \mathrm{C}$.

This is highly relevant to elite marathon swimming. Traditionally, open water swimmers had greater levels of subcutaneous fat than pool swimmers, ${ }^{21}$ but since the inclusion of marathon swimming in the Olympic Games programme, the body type of modern elite open water swimmers has moved towards them being lean, more like indoor swimmers. ${ }^{22}$ As a consequence, there is an argument for adjusting minimum water temperatures to protect the health of the athlete.

\section{Swimming capacity}

Tipton $e t a l^{2}$ noted the reduced swimming capability of moderately skilled swimmers; slower speed and stroke efficiency were associated with swim failure during 90 min swims. Such gradual performance decrements did not occur in the present study with elite swimmers. We noticed a binary pattern: swimmers either swam normally or, frequently, chose to stop before completion, 


\section{Original article}

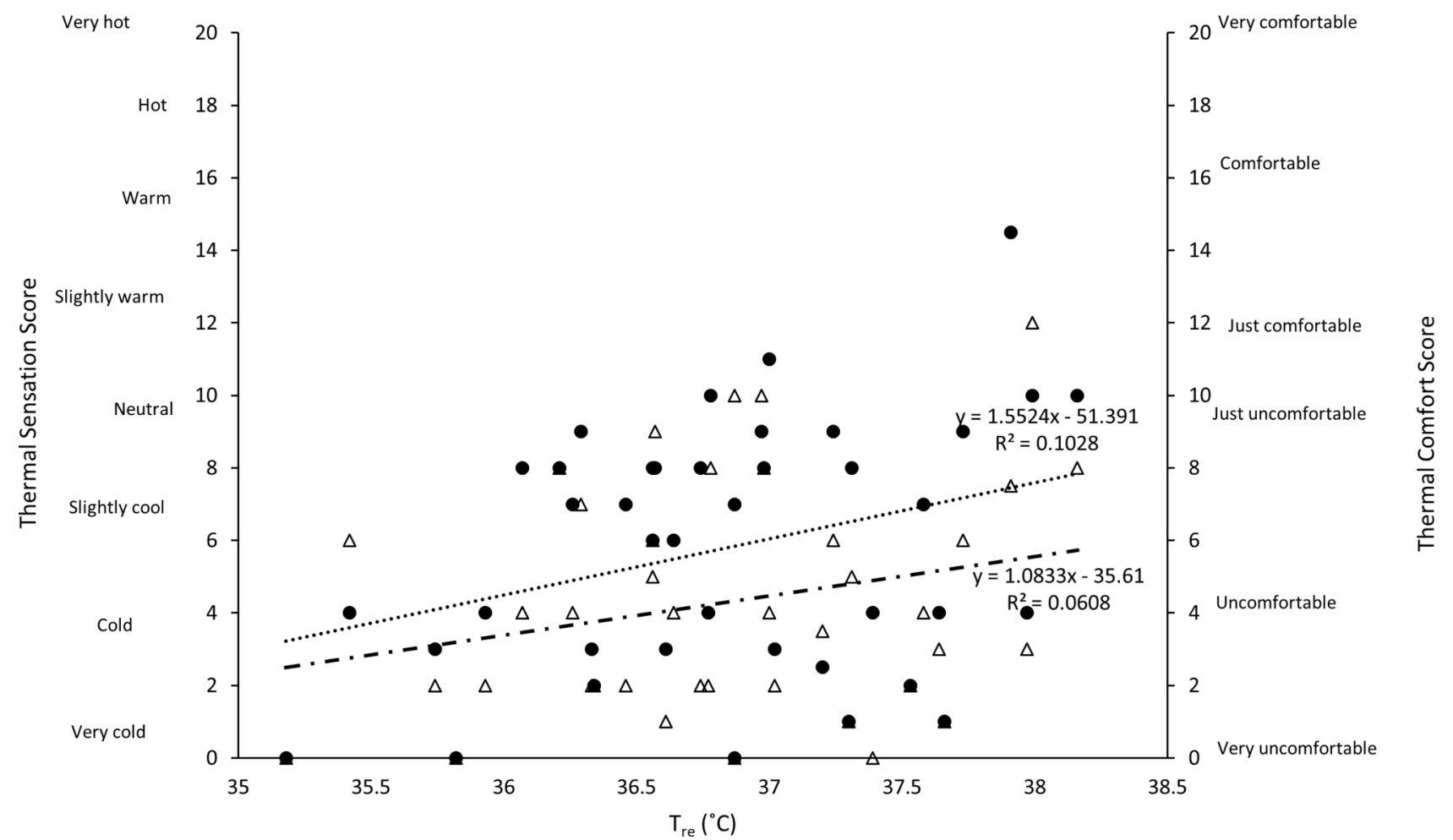

Figure 2 Thermal sensation and thermal comfort scores plotted against $T_{r e}$ for all participants in all conditions. $n=12$. Triangles=thermal sensation scores; circles=thermal comfort scores; dashed line=linear regression for thermal sensation; dotted line=linear regression for thermal comfort.

while some had to be withdrawn as their $\mathrm{T}_{\text {re }}$ reached $35^{\circ} \mathrm{C}$. The most common reason given for stopping was feeling 'too cold to swim', but it is unclear whether the swimmers would have stopped in a race with its greater incentive to continue.
We speculate that highly trained, motivated swimmers, with well-established swimming motor programmes, are more able to maintain performance when cold. This hypothesis requires testing.

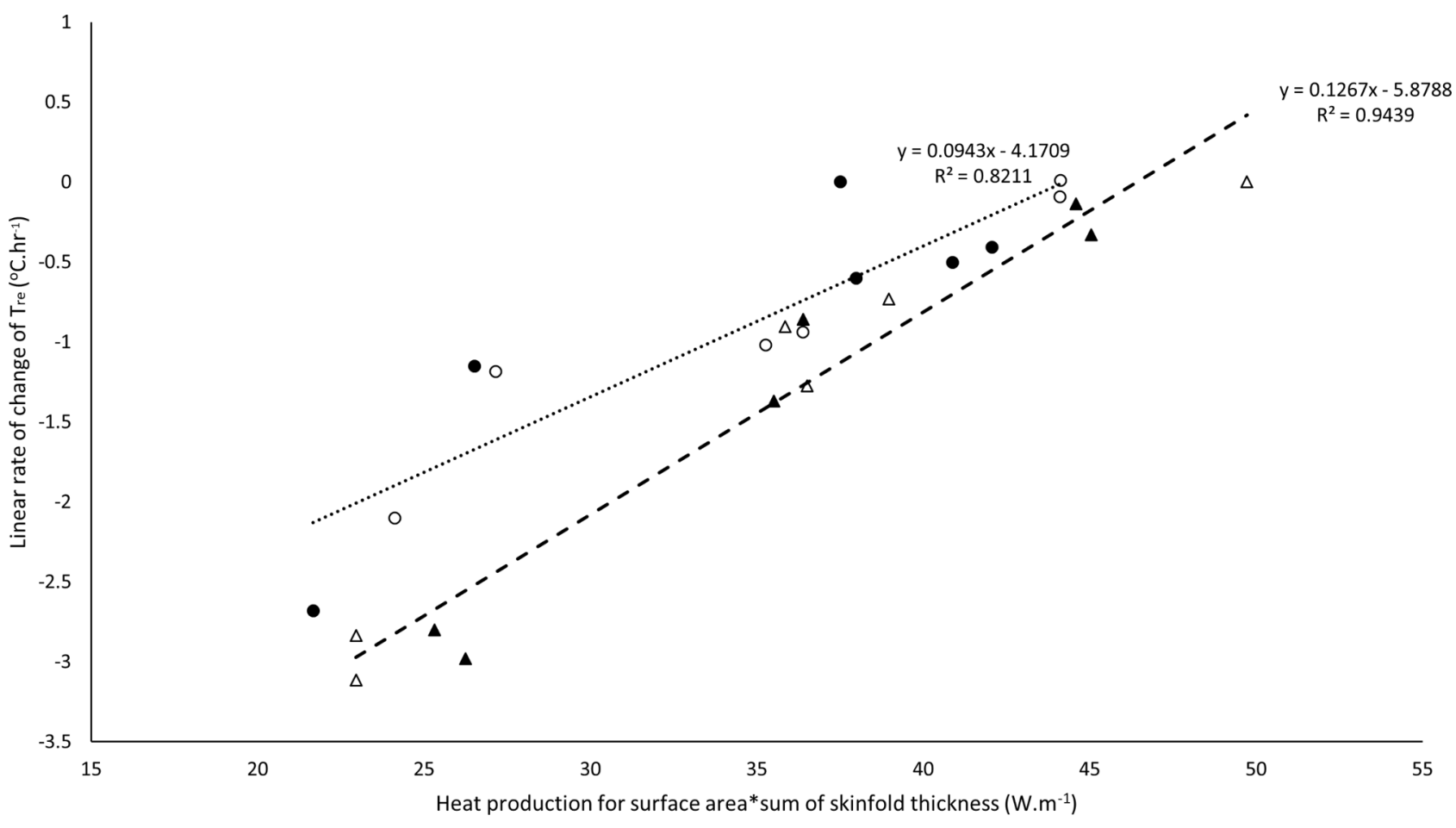

Figure 3 Sum of skinfolds * heat production for surface area plotted against linear rate of change of $\mathrm{T}_{\mathrm{r}}$. Triangles: $16^{\circ} \mathrm{C}$ condition; Circles: $18^{\circ} \mathrm{C}$ condition. Dashed line: linear regression for $16^{\circ} \mathrm{C}$ condition; dotted line: linear regression for $18^{\circ} \mathrm{C}$ condition. Open shapes: female swimmers; closed shapes: male swimmers. Leaner swimmers tend towards the lower end of the x-axis. 
Thermal perception

If swimmers are able to judge their own deep body temperature, they may be able to choose to withdraw from events before they become too cold. However, in the current study, swimmers' perception of their own deep body temperature was unreliable (Figure 1 and Tipton et $a l^{2}$ ). This contrasts with a similar study into upper water temperature limits, where swimmers were able to judge if deep body temperature was too high. ${ }^{23}$ There may be differential inputs into the perception of cooling and warming when in water.

In cool environments thermal perception arises from an unequal combination of skin and deep body temperature inputs, with skin temperature normally predominating. ${ }^{2425}$ The perception of cold on initial immersion in cold water is dominated by the dynamic response of the skin thermoreceptors; at this time, deep body temperature remains stable. The fact that there are roughly four times more cold receptors in the skin than warm receptors, but few direct cold receptors centrally, helps explain why cold perception depends on skin afferent input. By the time deep body temperature is falling and potentially contributing to the perception of body temperature (usually via the shivering evoked by such a fall-not present when exercising), skin temperate is clamped at about water temperature and contributes little to thermal sensation. In contrast, warm perception when in tepid/warm (as opposed to hot) water is more determined by increasing deep body temperature and mean body temperature as increasing peripheral blood flow exteriorises the core. In addition, warm receptors are abundant in deep body sites and relatively rarer in the skin. ${ }^{26}$ Cold habituated swimmers typically have a poor perception of their thermal state because cold acclimatisation makes the already poor relationship between thermal perception and thermal status worse. ${ }^{32127}$ Although the mechanism for this is unclear, the habituation occurs more centrally than the peripheral cold receptors ${ }^{28}$; it may relate to the process of hypothermic adaptation where a blunted sympathetic activation, with reduced levels of noradrenaline after a period of cold habituation, has been observed. ${ }^{29} 30$ The current study supported these suggestions, with one very well-acclimatised swimmer withdrawn from a $14^{\circ} \mathrm{C}$ swim when her $\mathrm{T}$ reached $35^{\circ} \mathrm{C}$, while her perception was that she was 'cool' and 'comfortable'. This would suggest that acclimatised open water swimmers cannot be relied on to assess their own deep body temperature while swimming. ${ }^{3}$ There are cases of swimmers swimming to unconsciousness (see Tipton $e t a l^{2}$ ).

\section{Factors involved in cooling-who is at risk?}

MHP reflects the heat a swimmer is producing, BSA indicates the surface area through which heat is lost by convection/ conduction, while SSF indicates the amount of insulation from subcutaneous fat available to a swimmer. ${ }^{14}{ }^{17}$ By combining MHP, BSA and SSF into one number, it was possible to see what proportion of heat loss could be explained by these factors and how much might be caused by other variables, such as peripheral blood flow. There was a strong correlation between SSF $\times$ MHP/BSA and the linear RoC of $\mathrm{T}_{\mathrm{re}}$, indicating that between $82 \%$ and $94 \%$ of the RoC in $\mathrm{T}_{\mathrm{re}}$ can be explained by these factors alone (Figure 2).

Swimmers with a low SSF $\times$ MHP/BSA score were most vulnerable to cooling - this was clear and predicted. This phenotype is very lean, tall and with low muscle mass or fitness (which will reduce the capacity for MHP). It is unknown how much MHP would change in a competitive situation. The most important element in explaining the variance in the change in $\mathrm{T}_{\mathrm{re}}$ was SSF (in $16^{\circ} \mathrm{C}$ : $\mathrm{R}^{2}=0.57$; in $18^{\circ} \mathrm{C}: \mathrm{R}^{2}=0.61$ ). The equation could (where MHP is known or accurately predicted) make it possible to predict how long a particular swimmer would be able to swim in $16^{\circ} \mathrm{C}$ and $18^{\circ} \mathrm{C}$ water, but the validity and predictive power of the equation needs to be confirmed in a different cohort of swimmers.

Previous studies have suggested that older people, women and those more acclimatised to cold might be more likely to cool quickly, although these studies largely involved passive immersion rather than swimming. ${ }^{31-33}$ Having already accounted for SSF, MHP and BSA, distinguishing between sexes did not improve the correlation between SSF $\times$ MHP/BSA and linear RoC of $\mathrm{T}_{\mathrm{re}}$. This suggests that in the cohort tested, sex per se was not an important factor in cooling rates. Our power was limited $(0.64)$ as we had only six swimmers of each sex. Additionally, there may also be less difference between the sexes in elite swimmers than in the non-athletic population.

The low number of participants and wide variation in age and acclimatisation status prevented useful statistical analysis of these factors; these could account for the small amount of the variation not explained by SSF $\times$ MHP/BSA.

\section{PRACTICAL RECOMMENDATIONS}

- The $16^{\circ} \mathrm{C}$ and $18^{\circ} \mathrm{C}$ water are too cold for many elite lean swimmers to complete a 2 -hour swim based on objective safety criteria applied to the athletes' performance in each condition.

- The minimum temperature for elite marathon racing should be changed to $20^{\circ} \mathrm{C}$.

\section{Implementation}

After being provided with these data, and taking other evidence into account, FINA amended the rules for racing in low water temperatures. In September 2017, FINA made wetsuit use compulsory in water temperatures below $18^{\circ} \mathrm{C}$ and optional in water temperatures below $20^{\circ} \mathrm{C}$ from $2017 .^{12} 13$

\section{What are the findings?}

- Most swimmers could not complete a 2-hour swim in $16^{\circ} \mathrm{C}$ water without becoming hypothermic.

- In $18^{\circ} \mathrm{C}$ water, a quarter of swimmers could not complete the swim without becoming hypothermic.

- Swimmers have a poor perception of their own deep body temperature.

- Rate of change of deep body temperature could be predicted by morphology and metabolic heat production.

How might it impact on clinical practice in the future?

- Fédération Internationale de Natation rules changed in 2017 to allow wetsuits in elite marathon swimming.

- Wetsuits are now compulsory in water temperatures below $18^{\circ} \mathrm{C}$ and optional below $20^{\circ} \mathrm{C}$.

Acknowledgements The study was funded by the Joint Medical Committee of the International Olympic Committee, Fédération Internationale de Natation and the International Triathlon Union. We would like to thank all the participants, technicians and data collection volunteers.

Contributors All coauthors contributed to the study design and data collection. JS processed and analysed the data and wrote the draft of the manuscript. All authors contributed to revising the draft of the manuscript.

Funding This work was funded by the Federation Internationale de Natation (FINA) Competing interests None declared. 
Ethics approval The study was approved by the University of Portsmouth Science Faculty Research Ethics Committee (code 2014-075).

Provenance and peer review Not commissioned; externally peer reviewed.

Data sharing statement All unpublished data are available on request to the corresponding author.

\section{REFERENCES}

1 Castellani JW, Young AJ, Ducharme MB, et al. American College of Sports Medicine position stand: prevention of cold injuries during exercise. Med Sci Sports Exerc 2006;38:2012-29.

2 Tipton M, Eglin C, Gennser M, et al. Immersion deaths and deterioration in swimming performance in cold water. Lancet 1999;354:626-9.

3 Tipton M, Bradford C. Moving in extreme environments: open water swimming in cold and warm water. Extrem Physiol Med 2014;3:1-21.

4 Rüst CA, Knechtle B, Rosemann T. Changes in body core and body surface temperatures during prolonged swimming in water of $10^{\circ} \mathrm{C}$-a case report. Extrem Physiol Med 2012;1:8.

5 FINA. Open Water Swimming Rules 2009-2013. 2013 http://www.fina.org/H2O/ index.php?option=com_content\&QJ;\&view=category\&id=83:open-water-swimmingrules\&\&QJ; Itemid=184\&layout=default.

6 Zhang Y, Zhao R, sensation Othermal. acceptability and comfort. Build Environ 2008;43:44-50.

7 Du Bois D, Du Bois E. A formula to estimate the approximate surface area if height and weight be known. Arch Intern Med 1916;17:863-71.

8 Asmussen E, NIELSEN M. The regulation of the body-temperature during work performed with the arms and with the legs. Acta Physio/ Scand 1947;14:373-82.

9 WEIR JB. New methods for calculating metabolic rate with special reference to protein metabolism. J Physiol 1949;109:1-9.

10 Toussaint HM, Knops W, De Groot G, et al. The mechanical efficiency of front crawl swimming. Med Sci Sports Exerc 1990;22:402???408-8.

11 Hopkins WG, Marshall SW, Batterham AM, et al. Progressive statistics for studies in sports medicine and exercise science. Med Sci Sports Exerc 2009;41:3-13.

12 FINA. FINA Rules for open water swimming. $2017 \mathrm{https}: / /$ www.fina.org/sites/default/ files/2017 2021 ows 11102017 ok.pdf.

13 FINA. FINA Memorandum on wetsuits for open water swimming. 2017:1-11 https:// www.fina.org/sites/default/files/wetsuits_for_ows_memo_nfs_11.01.2017_0.pdf.

14 Nadel ER, Holmér I, Bergh U, et al. Energy exchanges of swimming man. J Appl Physiol 1974;36:465-71.

15 Choi JS, Ahn DW, Choi JK, et al. Thermal balance of man in water: prediction of deep body temperature change. Appl Human Sci 1996;15:161-7.

16 Golden F, Tipton MJ. Essentials of Sea Survival: Human Kinetics, 2002.
17 Cannon P, Keatinge WR. The metabolic rate and heat loss of fat and thin men in heat balance in cold and warm water. J Physiol 1960;154:329-44.

18 Toner MM, Sawka MN, Pandolf KB. Thermal responses during arm and leg and combined arm-leg exercise in water. J Appl Physiol Respir Environ Exerc Physiol 1984;56:1355-60.

19 Golden FS, Tipton MJ. Human thermal responses during leg-only exercise in cold water. J Physiol 1987;391:399-405

20 Keatinge WR. The effects of subcutaneous fat and of previous exposure to cold on the body temperature, peripheral blood flow and metabolic rate of men in cold water. J Physiol 1960;153:166-78.

21 Pugh LG, Edholm OG. The physiology of channel swimmers. Lancet 1955;269:761-8.

22 VanHeest JL, Mahoney CE, Herr L. Characteristics of elite open-water swimmers. J Strength Cond Res 2004;18:302-5.

23 Bradford C, Gerrard D, Lucas , et al. Is swimming in warm water actually putting swimmers in hot water? Proc 15th Int Conf Environ Ergon 2013.

24 Nadel ER, Bullard RW, Stolwijk JA. Importance of skin temperature in the regulation of sweating. J App/ Physio/ 1971;31:80-7.

25 Frank SM, Raja SN, Bulcao CF, et al. Relative contribution of core and cutaneous temperatures to thermal comfort and autonomic responses in humans. J App/ Physiol 1999;86:1588-93.

26 Davey SL, Barwood MJ, Tipton MJ. Thermal perceptions and skin temperatures during continuous and intermittent ventilation of the torso throughout and after exercise in the heat. Eur J App/ Physiol 2013;113:2723-35.

27 Golden FS, Tipton MJ. Human adaptation to repeated cold immersions. J Physiol 1988;396:349-63.

28 Tipton MJ, Eglin CM, Golden FS. Habituation of the initial responses to cold wate immersion in humans: a central or peripheral mechanism? J Physiol 1998:512:621-8.

29 Mäkinen TM, Mäntysaari M, Pääkkönen T, et al. Autonomic nervous function during whole-body cold exposure before and after cold acclimation. Aviat Space Environ Med 2008;79:875-82

30 Leppäluoto J, Korhonen I, Hassi J. Habituation of thermal sensations, skin temperatures, and norepinephrine in men exposed to cold air. J Appl Physiol 2001;90:1211-8

31 Degroot DW, Kenney WL. Impaired defense of core temperature in aged humans during mild cold stress. Am J Physiol Regul Integr Comp Physiol 2007;292:R10 3-R108.

32 Tipton MJ, Wakabayashi H, Barwood MJ, et al. Habituation of the metabolic and ventilatory responses to cold-water immersion in humans. J Therm Biol 2013;38:24-31.

33 McArdle WD, Magel JR, Gergley TJ, et al. Thermal adjustment to cold-water exposure in resting men and women. J App/ Physiol Respir Environ Exerc Physiol 1984;56:1565-71. 